\title{
Oxidative stress of pregnancy and parturition on buffaloes and
}

\section{their calves}

\section{Saadia A. Ali}

Physiology Department Faculty of Veterinary Medicine, Suez Canal University, Egypt.

\section{العبء التأكسدي في الجاموس أثناء الحمل والولادة وكذلك الفحول المولودة}

صمدت هذه الدر اسة لتقييم العبء التأكسدي أثناء الحمل، الو لادة وفترة ما بعد الو لادة حتى ظهور أول شبق بعد الو لادة وكذلك في الفحول حتى عمر . 45 يوم أجريت هذه الدر اسة على عدد 10 من 10 من الجاموس الحو امل ـ تم أخذ عينات دم ابتدأ من الثهر الثاني من الحمل شهريا حتى الثهر العانشر ، 5 أيام قبل الو لادة، عند الو لادة، 5، 15 ،30 يوم بعد الو لادة و عند ظهور أول شبق بعد الو لادة.تم أيضا

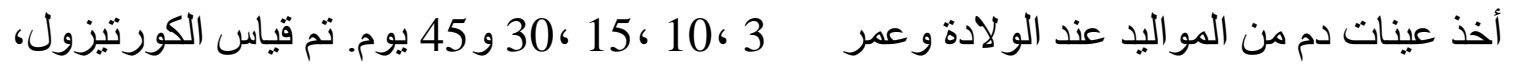
الكتاليز،السوبر أكسيد دسميوتيز ،الجلوتاثيون المختزل، المالوندالدهيد. فيتامين ج وهـ وكذلك الزنك و السلينيوم في مصل هذه الحيو انات. ازداد مستوى الكورتيزول و المالوندالدهيد خلال المر احل المتأخرة من الحمل وبعد الو لادة بينما فيتامين هـ أظهر انخفاضـا أثناء تللك الفترة.أظهر مستوى الكتاليز و الجلو تاثيون المختزل تقلبات مختلفة. ازداد مستوى الكورتيزول في الفحول حديثة الو لادة عند عمر 3 و 10 أيام. ازداد نشاط إنزيم الكتاليز مع تقدم العمر. السوبر أكسيد دسميوتيز ازداد عند عمر 30 و 45 يوم. الجلوتاثيون المختزل نقص عند عمر 3 أيام وبعد ذلك ازداد مع تقدم العمر. انخفض مستوى

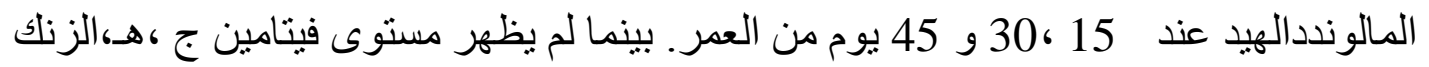
و السيلينيوم أي اختلافات ملحوظة.

\section{SUMMARY}

The present study was designed to evaluate oxidative stress of pregnancy, parturition and postpartum in buffalo cow as well as new born buffalo calves. Serum cortisol, catalase (CAT), superoxide dismutase (SOD), reduced glutathione (GSH), malondialdehyde (MDA), vitamin $\mathrm{C}$ and $\mathrm{E}$ as well as zinc and selenium levels were evaluated during pregnancy and around parturition till the $1^{\text {st }}$ postpartum estrous as well as in new born buffalo calves. 
In buffalo cows, serum cortisol and MDA levels were elevated through late pregnancy and postpartum while vitamin E level showed significant decrease through this period. Meanwhile, CAT and GSH values showed fluctuant variations. In newborn calves, serum cortisol increased on day 3 and 10. CAT increased with age progress. SOD increased on day 30 and 45 while GSH decreased on day 3 then it increased with advancement of age. MDA level decreased on days 15, 30 and 45. Serum levels of vitamins $E$ and $C$ as well as zinc and selenium did not show significant change.

It could be concluded from recurrent study that late pregnancy and parturition cause oxidative stress and consequently increase in serum cortisol in buffalo and newborn calves.

\section{INTRODUCTION}

Pregnancy, parturition and postpartum periods are critical for female animals. These activities are related to complex and specific metabolic processes regulated not only by steroid hormones and prostaglandins but also by other biological factors secreted by placenta or mammary gland as well as the whole body (Goff and Horst 1997). Pregnancy is a physiological state accompanied by a high energy demand for many bodily functions as a result of which an increased intake and utilization of oxygen takes place and thereby augmenting level of oxidative stress (OS). Oxidative stress affects multiple physiological processes from oocyte maturation to fertilization, embryo development and pregnancy (Agarwal et al., 2003). OS is favored during pregnancy mostly because of the mitochondria rich placenta (Mudron and Konvicna, 2006). It requires concert action of hormones that regulate appropriate development of placenta which in turn is responsible for the supply of nutrients for fetus. Body stores can be mobilized for this supply and 
increased metabolic activity can result in the increase of reactive oxygen species (ROS) production (Myatt and Cui, 2004 and Bernabucci et al., 2005). During parturition, not only hormonal concert action but also physical effort related to fetal expulsion takes place. These metabolic reactions may result in the overproduction of ROS (Miller et al., 1993 and Fainaru et al., 2002). Lactation also requires specific metabolic activity related to appropriate production of milk and ensure the supply of newborn with necessary nutrients and biologically active substances protecting it from ROS (Bell 1995). Active substances present in colostrum and milk are supposed to protect not only newborn but mammary gland as well (Lidmark-Mansson and Akesson, 2000). Peroxidation of lipids, proteins, carbohydrates as well as nucleic acids and their products can exert severe negative effects on cell membranes, biochemical pathways and influence the efficiency of anti-oxidative system. The examination of anti-oxidative and oxidative profile may help to answer whether living organism can cope with this imbalance or requires assistance to avoid clinical symptoms of disease. Anti-oxidative system represented by enzymes and non-enzymatic antioxidants is responsible for maintaining the balance between ROS production and neutralization (Halliwell and Gutteridge, 1990).

Therefore, the aim of this study was to monitor possible repeatability and similarity of reproductive cycles in buffalo cow by determination of antioxidants and oxidant during pregnancy, pre-partum, parturition and postpartum periods until the appearance of $1^{\text {st }}$ estrus as well as their calves.

\section{MATERIALS AND METHODS}

Ten healthy pregnant buffalo-cows were kept at farm of Fac. Vet. Med. Suez Canal Univ. included in the present study. Buffalo cows were fed on Egyptian clover (Barseem), concentrates and rice straw. A full case history, 
and general health conditions of each animal were recorded in the farm record. Gynecological examination was carried out by rectal palpation monthly starting from $2^{\text {nd }}$ month after natural mating. The pregnancy was confirmed by monitoring progesterone level ( > $2.8 \mathrm{ng} / \mathrm{ml}$ ) as reported by Singh et al., (2005). Progesterone level was assayed by ELIZA microwell technique using kits from DIMA (Germany) according to Hubl et al. (1982).

Individual blood samples were collected by direct vein-puncture of jugular vein monthly starting from $2^{\text {nd }}$ month until $10^{\text {th }}$ month of pregnancy, 5 days pre-parturient, on parturition day, on days 5, 15 and 30 postpartum as well as at appearance of $1^{\text {st }}$ postparturm estrus. Also, corresponding blood samples were collected from the newborns on parturition day and at 3,10,15, 30 and 45 days of age. Sera were separated by centrifugation at $1500 \mathrm{rpm}$. for $15 \mathrm{~min}$. and frozen at $-20^{\circ} \mathrm{C}$ for determination of cortisol, CAT, SOD, GSH and MDA according to Prakash and Madan (1995); Misera and Fridovich (1972); Aebi (1974); Anderson (1985) and Ohkawa et al. (1979), respectively. Tocopherol and ascorbic acid were determined according to Taylor et al. (1976) and Omaye et al. (1979) respectively. Zinc and selenium concentrations were determined by atomic absorption spectrophotometry (Varly et al. 1980).

Data were subjected to statistical analysis using SAS Program (1994) to determine ANOVA.

\section{RESULTS}

Pregnancy length calculated by date ranged between 311 and 319 days. All calving occurred during October 2010. Buffaloes were in $1^{\text {st }}$ estrous on 50-60 days after delivery. Serum cortisol level (Table 1) was significantly higher at $10^{\text {th }}$ month of pregnancy and on day 5 pre-partum, parturition, on 5 and 15 day post-partum as well as at $1^{\text {st }}$ estrous compared to other stage of 
pregnancy. Serum cortisol levels were significantly elevated in newborn buffalo calves on day 3 and 10 as compared with $1^{\text {st }}$ day of life (Table 2).

Serum CAT activity (Table 1) was significantly decreases in pregnant buffalo from $3^{\text {rd }}$ to $9^{\text {th }}$ month also on day 5 post-parturient. Serum CAT activity (Table 2) was significantly decrease in newborn buffalo calves on day 3 and 10 while it significantly increases on day 15,30 and 45 as compared with $1^{\text {st }}$ day of life. GSH concentration (Table 1) show conflicting levels among different months of pregnancy and post-parturient buffalo cow with lowest concentrations at $10^{\text {th }}$ month of pregnancy and on day 5 pre-partum, parturition, 5 day post-partum as well as at $1^{\text {st }}$ estrous. Serum GSH level (Table 2) was significantly decrease in new born buffalo calves on day 3 while it significantly increased on day $10,15,30$ and 45 as compared with $1^{\text {st }}$ day of life. SOD activity (Table 1 ) was significantly increased from $3^{\text {rd }}$ up to $8^{\text {th }}$ month, while it decreased from $10^{\text {th }}$ month of pregnancy up to 15 days postpartum and at appearance of $1^{\text {st }}$ estrous in buffalo. Serum SOD activity was significantly increased in newborn buffalo calves on day 30 and 45 as compared with $1^{\text {st }}$ day of life. MDA level (Table 2 ) was significantly higher at early and late pregnancy, parturition, post-partum until appearance of $1^{\text {st }}$ estrous compared to other stage of pregnancy. Serum MDA concentrations were significantly decrease in new born buffalo calves on day 15,30 and 45 as compared with $1^{\text {st }}$ day of life (Table 2). Vitamin E level was significantly decreases in pregnant buffalo from $9^{\text {th }}$ month and remains at low level till appearance of $1^{\text {st }}$ post-partum estrous. Vitamin C, zinc and selenium showed no significant change through pregnancy, parturition as well as post-partum period. Meanwhile, there was no significant difference in vitamin E, C, zinc, selenium with age progress in buffalo calves.

\section{DISCUSSION}


Cortisol hormone plays a very important role in many physiological functions, especially energy production (Habeeb et al., 2002). The present results showed higher cortisol levels at the $10^{\text {th }}$ month of pregnancy and on day 5 pre-partum, at parturition, on days 5 and 15 postpartum as well as at $1^{\text {st }}$ estrus compared to other stages of pregnancy. In cows, the effect of pregnancy on serum corticoid concentration revealed insignificant change but increased near parturition (Teama, 2009) which agree with the data of the present study. However, Prakash and Madan (1995) did not record fluctuation between day 30 pre- and day 2 postpartum. On the other side, serum cortisol levels were significantly elevated in newborn buffalo calves on day 3 and 10 as compared with $1^{\text {st }}$ day of life. The higher level of cortisol in neonatal calves may be related to the internal defense mechanism (Sharma et al., 2006). In this respect, higher cortisol levels were recorded in neonatal calves by Agarwal et al. (1985) during $1^{\text {st }}$ week and it might be due to increased activity of the adrenal cortex to combat the stressful external environment. This period is crucial as the internal defense of the calves is already poor and external stress is severe at this period of life. Another advantage of the higher cortisol during early neonatal life is to help the absorption of immunoglobulins by delaying the closure of the gut mucosa, and building up the internal defense. It seems that the increased levels of serum cortisol in the neonatal calves might be caused by gradual exposure of the calves to the external environment and stressful features that activated the adrenals of neonates to secrete higher amounts of cortisol to ameliorate the stress. The higher levels of the cortisol on days 3 and 10 as recorded in this study may be disadvantageous, for this might have reduced the internal defense through reduced phagocytic and antibody producing ability of the blood cells (Martin and Crump, 2003). Thus, the buffalo calves became prone to infection. 
CAT is an antioxidant enzyme responsible for breakdown of hydrogen peroxide. However, ROS produced during metabolism reduced the activity of CAT. In stressed animals, it could be correlated to increased generation of hydrogen peroxide (Patra and Swoup, 2000 and Gaal et al., 2006). Serum CAT activity was significantly decreased in pregnant buffalo from the $3^{\text {rd }}$ to $9^{\text {th }}$ month and also on day 5 postpartum. CAT activity was higher in pregnant buffalo $10^{\text {th }}$ month and on day 5 prepartieurent also on day 15,30 and day of $1^{\text {st }}$ estrous. These results agree with previous findings by Abdel-Kafy et al. (2008) who previously reported that catalase activity was increased in animals exposed to stress than control ones.

The role of SOD is to scavenge the superoxide produced by a number of reactions, including normal cellular functions. SOD catalyzes the dismutation of superoxide into oxygen and hydrogen peroxide. The current study revealed that the level of SOD during the $10^{\text {th }}$ month of pregnancy till 15 days postpartum was lower than that during the $2^{\text {nd }}$ month of pregnancy, suggesting oxidative stress induced at late pregnancy, parturition and lactation. Meanwhile, the higher mean value of MDA starting from the $10^{\text {th }}$ month of pregnancy till appearance of $1^{\text {st }}$ postpartum estrous in the present study, indicates higher lipid peroxidation of cell membranes as a result of higher oxidative stress in perparturient buffaloes (Bernabucci et al., 2002). MDA is produced during the reactive oxygen species (ROS) mediated peroxidation of polyunsaturated fatty acids under stress and is a widely used as a marker of oxidative stress (Burke et al., 2007 and Teama, 2009). It was also evident that after parturition the animal was relieved from stress of pregnancy and it was associated with high level of MDA from the day of parturition to appearance of $1^{\text {st }}$ estrus. This explains that after the animals are relieved from pregnancy and parturition stress, another immediate stress due to lactation is 
imposed on them, which is somewhat higher as compared to 3-8 months of pregnancy as strongest trend to metabolic imbalance is observed in dairy buffalo cows during early lactation resulting in an increased level of plasma MDA. This result is parallel to the finding of Mudron and Konvicna (2006) in cow. Oxidative stress due to embryo development and pregnancy, parturition as well as postpartum affects multiple physiological processes. OS was confirmed in the current study whereas buffalo cows showed increased MDA and decreased CAT, SOD and reduced glutathione (GSH-R). On the contrary, Castillo et al. (2004) showed that the reduction in MDA level was recorded in animals during late pregnancy and early lactation.

The present results showed that newborn buffalo calves are under oxidative stress as indicated by increased MDA levels through the $1^{\text {st }}$ and $3^{\text {rd }}$ days of life and decreased antioxidants markers (CAT, SOD and GSH). Newly born animals are mostly hyperactive and consume increased amount of oxygen with consequent generation of increased amount of free radicals. Therefore, sufficient antioxidants contents in their body and those supplied by maternal route are essential to blunt the excessive production of free radicals. In this respect, it was reported that antioxidant defense temper the negative influence of free radical and associated reaction and keep them in cheek (Priscilla and Heather, 2000 and Jens and Ove, 2006). Reduced activity of CAT in new born buffalo calves on day 3 and 10 in the present study may be correlated to increase generation of ROS (Patra and Swoup, 2000 and Gaal et al., 2006). On the other hand, ROS can diminish the activity of SOD followed by induction of its biosynthesis as a protective mechanism against free radical toxicity (Patra and Swoup, 2000 and Jens and Ove, 2006).

Vitamin E level was significantly decreased in pregnant buffalo from the $9^{\text {th }}$ month and remains at low level till appearance of the $1^{\text {st }}$ postpartum 
estrous. Vitamin C, zinc and selenium showed no significant change throughout pregnancy, parturition and postpartum periods. Meanwhile, in the present study there was no significant difference in contents of vitamin E, C, zinc and selenium with age progress in buffalo calves. The concentration of these elements depends upon the nutritional status of the calves and their dams (Zaki, 2003). Sikka et al. (2002); Malbe et al. (2003); Paulla-lopes et al. (2003) and Ahmed et al. (2010) reported that micronutrients such as $\mathrm{Zn}, \mathrm{Cu}$, Fe and Mn improved the efficiency of antioxidant system in lipid peroxidation prevention and support body defense mechanism. Vitamin $\mathrm{E}$ and $\mathrm{C}$ as well as zinc and selenium are useful in reducing the effects of stress (Priscilla and Heather, 2000; Chan, 2003; Sathya, et al., 2007; Sattar et al., 2007 and Ahmed et al., 2010). Therefore, the present results add complementary information about the metabolic status of pregnant buffalo and their calves as well as clarify the physiological effect of pregnancy and parturition on antioxidant defense system.

From this study, it could be concluded that late pregnancy and parturition cause oxidative stress and consequently increase in serum cortisol in buffalo and newborn buffalo calves.

\section{REFERANCE}

Abdel-Kafy, E.M., Ali, W.A.H., Hoda, A.S. and Azoz, A.A.A., (2008): Effect of short heat exposure, balanced feed restriction and acetic acid supplement at post weaning on growth and thermoregulation in growing rabbits during hot season. J. Nutr. Digest.Ph., 38: 507, 511.

Aebi, H. (1974): Catalase. In : Bergmeyer, HU (ed.), Methods of Enzymatic Analysis. Academic Press Inc, Verlag, NY, 2 : 673-685. 
Agarwal, S. P., V. K. Agarwal, I.J. Sharma and P.K. Dwaraknath.(1985):

Change in serum cortisol levels of male buffalo calves from birth to maturity. Indian J. Anim. Sci., 55 (12): 1001-1005.

Agarwal, A.; Saleh, R.A. and Bedaiwy, M.A.(2003): Role of reactive oxygen species in the pathophysiology of human reproduction. Fertil. Steril., 79:829843.

Ahmed W.M., El-khadrawy H.H., Emtenan M. Hanafi , Amal H. Ali and Shalaby S.A.(2010): Clinical prespective of repeat breeding syndrome in buffaloes. Journal of American Science, 6(12):1325-1331.

Anderson M. E.(1985): Determination of glutathione and glutathione disulphide in biological samples.,Method. Enzymol., 113:548-551.

Bell AW,(1995): Regulation of organic nutrient metabolism during transition from late pregnancy to early lactation. J Anim Sci 73, 2804-2819.

Bernabucci U., Ronchi B., Lacetera N. and Nardone A .(2002): Markers of oxidative status in plasma and erythrocytes of transition dairy cows during hot season. J. Dairy Sci. 95: 2173-2179.

Bernabucci U, Ronchi B, Lacetera N and Nardone A,( 2005): Influence of body condition score on relationship between metabolic status and oxidative stress in periparturient dairy cows.J. Dairy Sci.98, 2017-2026.

Burke, N.C., Scaglia, G., Saker, K.E., Blodgett, D.J. and Sweeker, W.S. Jr., Oxidative substances and plasma antioxidative capacity in cows J. Anim. Sci., 85, 2932-2940 (2007).

Chan,A.C.(2003): Partners in defense, vitamin E and vitamin C. Can. J. Physiol . Pharmacol., 71:725-731.

Castillo, C., Hernandez, J., Valverde, I., Pereira, V., Sotillo, J., Lopez, M. and Benedito, J., (2004): Oxidative stress and some antioxidant marker in pregnant cows J. Veterinary Sci., 80, 2, 133-139. 
Fainaru O, Almog B, Pinchuk I, Kupferminc MJ, Lichtenberg D. and Many A, (2002):Active labour is associated with increased oxidisibility of serum lipids ex vivo. BJOG 109, 938-941.

Gaal, T., K. Ribiezenyne-Szabo, K. Stadler, J. Jakus and J. Reiczigel (2006): Free radicals, lipid peroxidation and antioxidant system in the blood of cows and newborn calves around calving. Biochem. Mol. Biol., 143: 391-396.

Goff, JP.and Horst RL., (1997): Physiological changes at parturition and their relationship to metabolic disorders. J Dairy Sci 80, 1260-1268.

Habeeb, A.A.M., Abdel-Samee, A.M. and Aboulnaga, A.I., (2002): Effect of heat stress, feed supplementation and cooling technique on milk yield, milk composition and some blood constituents in Frisian cows under Egyptian conditions. Egyptian J. Appl. Sci., 17, 389-404.

Halliwell B. and Gutteridge JMC,(1990): Role of free radicals and catalytic metal ions in human disease: an overview. Methods Enzymol 186, 1-85.

Hubl,W., T. Fehert, W. Ronde, G. Domer, H. Taubert and E. Freyman, (1982): Determination of progesterone. Endokrionlogie, 79: 165.

Jens, L. and S. Ove, (2006): Oxidants and antioxidants in disease: Oxidative stress in farm animals. Vet. J., 10: 1016-1016.

Lidmark-Mansson H and Akesson B.(2000): Antioxidative factors in milk. Br. J. Nutr. 84, 103-110.

Malbe, M., E. Klassen, L. Kaartinen, M. Attla and F. Atrosh, (2003): Effect of oral selenium supplementation on mastatis and pathogens in estonian cows. Vet. Therap., 4: 145-154.

Martin,P.A. and M.H. Crump.(2003): The Adrenal Gland. In Pineda M.H.(ed.). McDonald's Veterinary Endocrinology. Iowa state Press. pp.165200. 
Miller JK, Brzezinska-Slebodzinska E. and Madsen FC,(1993): Oxidative stress, antioxidants and animal function. J Dairy Sci 76, 2812-2823.

Misera H., P. and Fridovich,J. (1972): The role of superoxide anion in the auto-oxidation of epinephrine and a simple assay for superoxide dismutase. J.Biol. Chem.247,3170.

Mudron P and Konvicna J (2006): Thiobarbituric acid reactive substances and plasma antioxidative capacity in dairy cows at different lactation stages. Deutsche tierärztliche Wochenschrift. 113:189-190.

Myatt L. and Cui X., (2004): Oxidative stress in the placenta. Histochem Cell Biol 122, 369-382.

Ohkawa H., Kaneko H. and Tsuji H.,(1979): Metabolism of fenvalerate (Sumicidin) in rats. J Pestic Sci 4:143-155.

Omaye ST., Turnbull JD. and Sauberlich HE.(1979): Vitamin C determination. Meth. Enzymol. 63,3-11.

Patra, C.R. and D. Swoup, (2000): Effect of lead on erythrocytic antioxidant defence, lipid peroxide level and thiol groups in calves. Res. Vet. Sci., 68: 7174.

Paul-alopes, F.F., Y.M. AlKatanani, A.C. Majewski and L.R. McDowell, (2003):Manipulation of antioxidant status fails to improve fertility of lactating cows or survival of heat-shocked embryos.J.Dairy Sci.,86:2343-2351.

Prakash, B.L. and M.L. Madan,(1995): Radioimmunoassay of cortisol in peripheral blood plasma of buffaloes peripartum. National symposium on Modern Trends in Reproductive Health care for Enhancing Livestock Fertility and Productivity. January 13-15, Akola. pp. L-11.

Priscilla, C.M. and S.T. Heather,(2000): Antioxidants: What role do they play in physical activity and health. Am. J. Clin. Nutr., 72: 637s-646s. SAS Program (1994): SAS User Guide Statistics. SAS Inst.Carry, NC.,USA. 
Sathya A., Prabhakar S., Sangha SP.and Ghuman SP.,(2007): Vitamin E and selenium supplementation reduces plasma cortisol and oxidative stress in dystocia-affected buffaloes. Vet. Res. Commun.,31(7):809-18.

Sattar, A.; Mirza,R.H. and S. M. I. Hussanin,S.M.I.(2007): Effect of prepartum treatment of vitamin $\mathrm{E}$ - selenium on postpartum reproductive and productive performance of exotic cows and their calves under subtropical conditions. Pakistan Vet. J., 27(3): 105-108.

Sharma,I.J., JainA.K. and Tripath R.K.(2006): A significant observation on the status of cortisol in neonatal buffalo calves and cow calves vis-vis their dams. Buffalo Bulletin Vol.25 (2) 30-36.

Sikka, P., D. Lall, A. Arora and K.R. Sethi, (2002): Growth and passive immunity in response to micronutrient supplementation in new-born calves of Murrah buffaloes given fat soluble vitamins during late pregnancy. J. Egypt. Vet. Med. Assoc., 75: 301-311.

Singh,B.; Saravia, F.; Bage, R. and Rodríguez-Martínez ,H. (2005): Pregnancy rates in repeat breeder heifers following multiple artificial inseminations during spontaneous oestrus . Acta Vet. Scand; 46(1): 1-12.

Taylor,S.L., Lamden,M.P. and Tappel,A.L.(1976): Sensitive fluorometric method for tissue tocopherol analysis. Lipids, 11, 530-538.

Teama, F.E.(2009): Evaluation of oxidative stress and some antioxidant marker in pregnant cows under summer conditions. ISOTOPE \& RAD. RES., 41, 4(suppl. 2), 1379-1390.

Varly, H., A.H. Gwenlock and M. Bell, (1980): Practical Clinical Chemistry. Vol. 1. General Topics Commoner Test. 5th Edn., William Heinemann Medical Books Ltd., London, UK. 
Zaki, E.R., (2003): Evaluation of the efficacy of some vaccines used for production of newborn buffalo calves against E. coli k99 by using ELISA. J. Egypt. Vet. Med. Assoc., 63: 275-284. 